American Journal of Applied Sciences 8 (1): 9-14, 2011

ISSN 1546-9239

(C) 2010 Science Publications

\title{
Combined Partial Oxidation and Carbon Dioxide Reforming Process: A Thermodynamic Study
}

\author{
Sompop Jarungthammachote \\ Department of Mechanical Engineering, Kasetsart University Si Racha Campus, \\ Sukhumvit Road, Si Racha, Chonburi, 20230, Thailand
}

\begin{abstract}
Problem statement: $\mathrm{CO}_{2}$ reforming is one of the methods to utilize a greenhouse gas to produce syngas, an important feed for methanol and Fischer-Tropsch synthesis. However, $\mathrm{CO}_{2}$ reforming is strong endothermic reaction requiring large amount of supplied energy. Partial oxidation, an exothermic reaction, is combined with $\mathrm{CO}_{2}$ reforming to serve the energy requirement. Thus, the optimum ranges of $\mathrm{O}_{2}$ and $\mathrm{CO}_{2}$ fed to the process corresponding to feedstock are needed to find. Moreover, one of the most important problems found in this process is solid carbon formation. Therefore, the operating range in which the carbon formation can be avoided is also required to study. Approach: In this study $\mathrm{CH}_{4}$ was used as feedstock. The optimum rage of $\mathrm{O}_{2}$ and $\mathrm{CO}_{2}$ fed to the process was found by using thermodynamic equilibrium method based on minimization of Gibbs free energy. The Lagrange multiplier method was conducted to form the equations and they were solved by the Newton-Raphson method. The solid carbon formation zone was also simulated. Results: The simulation showed that higher reaction temperature caused higher $\mathrm{CH}_{4}$ and $\mathrm{CO}_{2}$ conversions. Syngas production increased with increasing temperature. Operating the process with high temperature or high $\mathrm{O}_{2} / \mathrm{CH}_{4}$ and $\mathrm{CO}_{2} / \mathrm{CH}_{4}$ rations could eliminate solid carbon formation. Increase of $\mathrm{O}_{2} / \mathrm{CH}_{4}$ ration higher than 0.1 led decreasing syngas while increase of $\mathrm{CO}_{2} / \mathrm{CH}_{4}$ ration caused increasing $\mathrm{H}_{2}$ and $\mathrm{CO}$. However, when $\mathrm{CO}_{2} / \mathrm{CH}_{4}$ ration was higher than 0.85 , increasing $\mathrm{CO}_{2} / \mathrm{CH}_{4}$ ration showed insignificant change of syngas concentration. Conclusion: The combined partial oxidation and $\mathrm{CO}_{2}$ reforming of method should be operated with reaction temperature of $1050 \mathrm{~K}$. The optimum range of $\mathrm{CH}_{4}: \mathrm{CO}_{2}: \mathrm{O}_{2}$ for this process is 1: 0.85-1.0:0.1-0.2.
\end{abstract}

Key words: Partial oxidation, carbon dioxide reforming, syngas production, solid carbon formation, greenhouse gases, increasing temperature, Fischer-Tropsch, thermodynamic study

\section{INTRODUCTION}

$\mathrm{CO}_{2}$ is one of the most important greenhouse gases produced from combustion process (Al-Mutairi and Koushki, 2009; Bundela and Chawla, 2010; Khademi et al., 2009). It can be utilized as reactant for hydrocarbon reforming to produce synthesis gas (also called syngas). The syngas, which consists of $\mathrm{H}_{2}$ and $\mathrm{CO}$, is a feedstock for the methanol and FischerTropsch syntheses (Tsang et al., 1995; Froment, 2000). $\mathrm{CO}_{2}$ reforming process is sometime called dry reforming, which is strong endothermic reaction. Thus, it requires large amount of heat supplied to the process. $\mathrm{CO}_{2}$ reforming has been widely investigated (Edwards, 1995; Wurzel et al., 2000; Nagaoka et al., 200; Li et al., 2004). Both equilibrium model simulation and experiment were conducted by Haghighi et al. (2007) to study $\mathrm{CO}_{2}$ reforming of $\mathrm{CH}_{4}$. The result has been presented that equilibrium $\mathrm{H}_{2} / \mathrm{CO}$ ratio at high temperature was about 1.0. However, at a specific temperature, higher pressure caused lower $\mathrm{H}_{2} / \mathrm{CO}$ ratio.
Moreover, the authors indicated that a deposited carbon was also one of the major products obtained from $\mathrm{CO}_{2}$ reforming. For coke (carbon) formation, it has been mentioned by many researchers that it is an important problem of the dry reforming reaction, because it leads to catalyst deactivation (Wurzel et al., 2000; Nagaoka et al., 200; Shamsi and Johnson, 2003).

Partial oxidation of hydrocarbon can be explained as a sub-stoichiometric combustion process and it is an exothermic reaction. The thermodynamic equilibrium of ethanol partial oxidation has been studied by Wang and Wang (2008). At complete conversion, 86.28$94.98 \%$ yield of hydrogen and $34.69-38.64 \%$ concentration of CO could be achieved at 1070-1200 K. Partial oxidation of methane to hydrogen and carbon monoxide over a $\mathrm{Ni} / \mathrm{TiO}_{2}$ catalyst has been experimentally investigated (Wu et al., 2005). Use of fixed-bed reactors for the partial oxidation has shown a drawback of hot spot (Puwanto and Muharam, 2006). Hot spot formation is a common problem found in catalytic partial oxidation (Naito et al., 2008) and it can cause deactivation of catalysts. 
From the above information, the idea to combine the partial oxidation and $\mathrm{CO}_{2}$ reforming processes is presented to solve the high energy requirement problem of $\mathrm{CO}_{2}$ reforming. Heat produced from partial oxidation process is supplied to $\mathrm{CO}_{2}$ reforming process. Therefore, the combined process is a thermally selfsustaining and may not need to consume external thermal energy. The combination of exothermic and endothermic reactions is called autothermal reaction. The combined steam reforming and partial oxidation, which is the well known hydrogen production process, is an example of the autothermal reaction.

In this study, the partial oxidation process combined with $\mathrm{CO}_{2}$ reforming process is investigated through thermodynamic equilibrium model. Methane is chosen as feedstock. The effect of reaction temperature on $\mathrm{CH}_{4}$ and $\mathrm{CO}_{2}$ conversions is focused. Moreover, the reaction temperature is varied to observe the change of concentration of products. The formation of coke (carbon) is an important issue examined in this study. The effects of $\mathrm{CO}_{2} / \mathrm{CH}_{4}$ and $\mathrm{O}_{2} / \mathrm{CH}_{4}$ ratios on syngas production are also presented. Finally, the optimum condition to syngas yield is suggested.

\section{MATERIALS AND METHODS}

Chemical reactions: The major gas species considered in this study are $\mathrm{CH}_{4}, \mathrm{CO}, \mathrm{CO}_{2}, \mathrm{H}_{2}$ and $\mathrm{H}_{2} \mathrm{O}$. Solid carbon is also observed. The partial oxidation combined with $\mathrm{CO}_{2}$ reforming of methane is involved with the predominance chemical reactions, which are listed below:

$$
\begin{aligned}
& \mathrm{CH}_{4}+2 \mathrm{O}_{2} \rightarrow \mathrm{CO}_{2}+2 \mathrm{H}_{2} \mathrm{O} \\
& \mathrm{CH}_{4}+\frac{1}{2} \mathrm{O}_{2} \rightarrow \mathrm{CO}+2 \mathrm{H}_{2} \\
& \mathrm{CH}_{4}+\mathrm{H}_{2} \mathrm{O} \leftrightarrow \mathrm{CO}+3 \mathrm{H}_{2} \\
& \mathrm{CH}_{4}+2 \mathrm{H}_{2} \mathrm{O} \leftrightarrow \mathrm{CO}_{2}+4 \mathrm{H}_{2} \\
& \mathrm{CH}_{4}+\mathrm{C}_{2} \mathrm{O} \leftrightarrow 2 \mathrm{CO}+2 \mathrm{H}_{2} \\
& \mathrm{CO}+\mathrm{H}_{2} \mathrm{O} \leftrightarrow \mathrm{CO}_{2}+\mathrm{H}_{2} \\
& 2 \mathrm{CO} \leftrightarrow \mathrm{CO}_{2}+\mathrm{C} \\
& \mathrm{CH} \leftrightarrow 2 \mathrm{H}_{2}+\mathrm{C}
\end{aligned}
$$

The chemical equilibrium model: The chemical equilibrium model can be categorized into 2 types. The first one is equilibrium model based on equilibrium constants. It is known as the stoichiometric model. This method requires the information of chemical reactions occurring in the process. Another kind of equilibrium model is non-stoichiometric model, so called the minimization of Gibbs free energy method in which no chemical reactions are involved. The equilibrium model used in this study is developed following the method discussed in Ref (Jarungthammachote and Dutta, 2008; Jarungthammachote, 2009). At equilibrium state, the total Gibbs free energy of the system is minimized. The total Gibbs free energy of system is defined as:

$$
G^{t}=\sum_{i=1}^{N} n_{i} G_{i}=\sum_{i=1}^{N} n_{i} \mu_{i}
$$

Where:

$\mathrm{n}_{\mathrm{i}}$ and $\mu_{\mathrm{i}}=$ The number of moles and the chemical potential of species $i$, respectively

$\mathrm{G}_{\mathrm{i}} \quad=$ The partial molar Gibbs free energy of species i

If all gases are assumed as ideal gas and all reactions take place at one atmospheric pressure. The chemical potential of species i can be presented by:

$\mu_{\mathrm{i}}=\Delta \overline{\mathrm{G}}_{\mathrm{f}, \mathrm{i}}^{\mathrm{o}}+\mathrm{RT} \ln \left(\mathrm{y}_{\mathrm{i}}\right)$

Where:

$\mathrm{R}$ and $\mathrm{T}=$ The universal gas constant and temperature, respectively

$\mathrm{y}_{\mathrm{i}} \quad=$ The mole fraction of gas species $\mathrm{i}$ and it is the ratio of $n_{i}$ and the total number of moles in the reaction mixture

$\Delta \overline{\mathrm{G}}_{\mathrm{f}, \mathrm{i}}^{\mathrm{i}} \quad=$ The standard Gibbs free of formation of species i

For solid carbon, the partial molar Gibbs free energy is:

$\mathrm{G}_{\mathrm{C}(\mathrm{S})} \cong \Delta \overline{\mathrm{G}}_{\mathrm{f}, \mathrm{C}(\mathrm{S})}^{\mathrm{T}}$

To find the minimum point, the Lagrange multiplier method is conducted with constraint of mass balance, i.e.:

$\sum_{i=1}^{N} a_{i j} n_{i}=A_{j}, j=1,2,3, \ldots, k$

Where:

$a_{i j}=$ The number of atom of the jth element in a mole of the ith species

$A_{j}=$ Defined as the total number of atom of $j$ th element in the reaction mixture

From Eq. 9-12, Lagrangian function is formed and partial derivative is applied. The final simultaneous equations, therefore, can be developed as:

$$
\frac{\Delta \overline{\mathrm{G}}_{\mathrm{f}, \mathrm{i}}^{\mathrm{o}}}{\mathrm{RT}}+\ln \left(\frac{\mathrm{n}_{\mathrm{i}}}{\mathrm{n}_{\mathrm{tot}}}\right)+\sum_{\mathrm{j}=1}^{\mathrm{k} T} \frac{\lambda_{\mathrm{j}}}{\mathrm{RT}} \mathrm{a}_{\mathrm{i}, \mathrm{j}}=0, \quad \mathrm{i}=1, \ldots, \mathrm{N}
$$


where, $\lambda_{\mathrm{j}}, \lambda=\lambda_{1}, \ldots, \lambda_{\mathrm{k}}$ are Lagrange multipliers.

The solutions $n_{i}$ have to be real numbers in the boundary such that $0 \leq \mathrm{n}_{\mathrm{i}} \leq \mathrm{n}_{\text {tot }}$. Equation 13 creates the set of non-linear equations and those are solved along with constraint equations by iteration technique, the Newton-Raphson method. The data from the NASA technical memorandum 4513 (McBride et al., 1993) is employed to calculate all thermodynamic properties in this model.

\section{RESULTS AND DISCUSSION}

The effect of temperature on reactant conversions and gas yields: The simulation of combined partial oxidation and $\mathrm{CO}_{2}$ reforming was conducted with $\mathrm{CH}_{4}: \mathrm{CO}_{2}: \mathrm{O}_{2}$ feed ratio of 1.0:1.0:0.2. The conversion of reactants affected by reaction temperature is shown in Fig. 1. The conversions of $\mathrm{CH}_{4}$ and $\mathrm{CO}_{2}$ are defined in Eq. 14 and 15, respectively:

$$
\begin{aligned}
& \mathrm{CH}_{4} \text { conversion }(\%)=\frac{\left(\mathrm{CH}_{4, \text { in }}-\mathrm{CH}_{4, \text { out }}\right)}{\mathrm{CH}_{4, \text { in }}} \times 100 \\
& \mathrm{CO}_{2} \text { conversion }(\%)=\frac{\left(\mathrm{CO}_{2, \text { in }}-\mathrm{CO}_{2, \text { out }}\right)}{\mathrm{CO}_{2, \text { in }}} \times 100
\end{aligned}
$$

where subscripts in and out represent mole of substance at the inlet and outlet, respectively.

From Fig.1, it can be observed that the temperature strongly affects on $\mathrm{CH}_{4}$ conversion. It increases when temperature increases. The conversion of $95 \%$ of $\mathrm{CH}_{4}$ can be achieved at reaction temperature of $1050 \mathrm{~K}$. For $\mathrm{CO}_{2}$ conversion, it increases with increasing temperature. At higher temperature, $\mathrm{CO}_{2}$ conversion dramatically increases because $\mathrm{CO}_{2}$ reforming is endothermic reaction favoring high temperature. This reason is supported by increasing $\mathrm{CO}$ concentration when temperature increases, which is discussed in Fig. 2.

The equilibrium products from partial oxidation and $\mathrm{CO}_{2}$ reforming are exhibited in Fig. 2. Increase of $\mathrm{CO}$ mole fraction shows similar trend as $\mathrm{CO}_{2}$ conversion. As previously mentioned, high temperature favors $\mathrm{CO}_{2}$ reforming and it produces $\mathrm{CO}$. For $\mathrm{H}_{2}$, its concentration increases with increasing temperature. However, at temperature higher than $1000 \mathrm{~K}$, mole fraction of $\mathrm{H}_{2}$ is quite constant. This is because $\mathrm{CO}_{2}$ reforming and reverse water gas shift reactions are endothermic. High temperature not only supports $\mathrm{CO}_{2}$ reforming reaction to product $\mathrm{H}_{2}$ but also favors reverse water gas shift reaction to consume $\mathrm{H}_{2}$. Decreasing $\mathrm{H}_{2} \mathrm{O}$ is clearly observed at high temperature. That is the effect of reactions (3) and (4), which are strong endothermic reactions.

Figure 3 illustrates $\mathrm{H}_{2} / \mathrm{CO}$ ratio and syngas $\left(\mathrm{H}_{2}+\mathrm{CO}\right)$ production from combined partial oxidation and $\mathrm{CO}_{2}$ reforming. The value of $\mathrm{H}_{2} / \mathrm{CO}$ ratio is higher at lower temperature. At $800 \mathrm{~K}, \mathrm{H}_{2} / \mathrm{CO}$ ratio is about 5, while $\mathrm{H}_{2} / \mathrm{CO}$ ratio is 1.09 at $1000 \mathrm{~K}$. It is clearly seen that $\mathrm{H}_{2} / \mathrm{CO}$ ratio approaches to 1 at high temperature. This also confirms that $\mathrm{CO}_{2}$ reforming is predominant (reaction (5)) at high temperature. However, at low temperature, the influence of partial oxidation of methane (reaction (2)) outstandingly

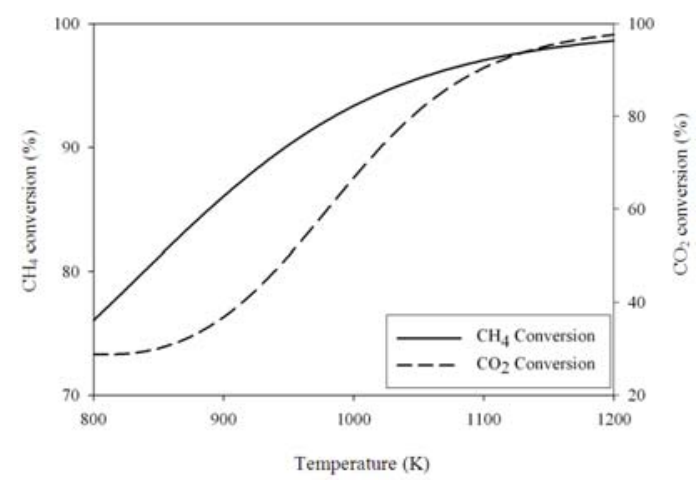

Fig. 1:Effect of temperature on $\mathrm{CH}_{4}$ and $\mathrm{CO}_{2}$ conversions

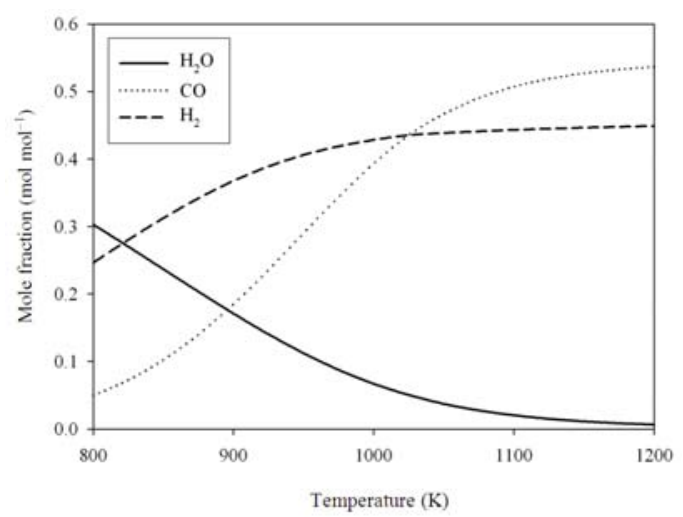

Fig. 2: Effect of temperature on reaction products

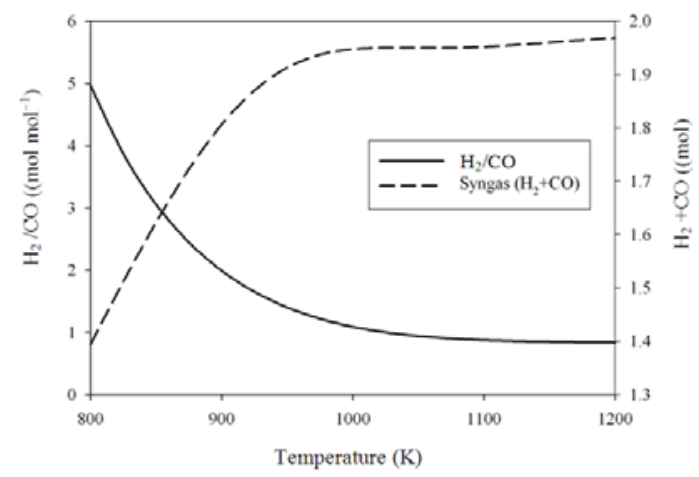

Fig. 3: Effect of temperature on $\mathrm{H}_{2} / \mathrm{CO}$ ration and syngas production 
Am. J. Applied Sci., 8 (1): 9-14, 2011

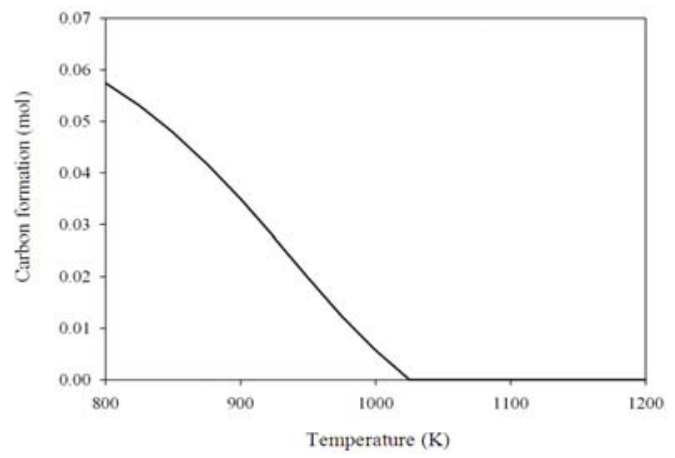

Fig. 4: Effect of temperature on solid carbon formation

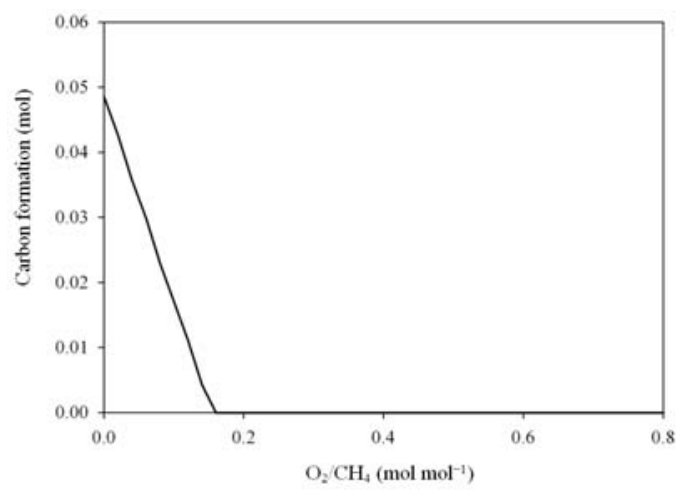

Fig. 5: Carbon formation affected by $\mathrm{O}_{2} / \mathrm{CH}_{4}$ ration

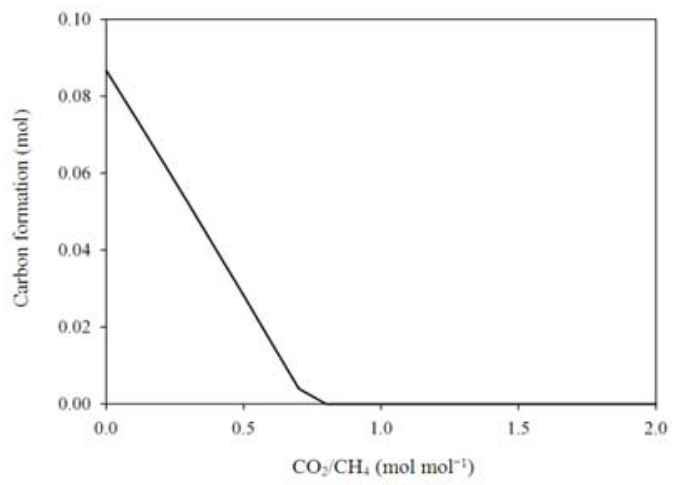

Fig. 6: Carbon formation affected by $\mathrm{CO}_{2} / \mathrm{CH}_{4}$ ration

presents. For syngas, it dramatically increases at low temperature and slightly changes after $1000 \mathrm{~K}$. For Fig. 3, syngas production is about $5.5 \mathrm{~mol}$ for feeding $1 \mathrm{~mol}$ of $\mathrm{CH}_{4}$ if the reactor is operated at temperature higher than $1000 \mathrm{~K}$.

The solid carbon formed in this process is also investigated. It is an undesired component because it deactivates the catalyst and causes pressure drop in reactor. From Fig. 4, it elucidates that mole fraction of carbon formed in the process decreases with the increase in temperature. The solid carbon cannot be found when reaction temperature is higher than $1025 \mathrm{~K}$.

Carbon formation: To study more about carbon formation in combined partial oxidation and $\mathrm{CO}_{2}$ reforming process, the simulation is carried out at the reaction temperature of $1050 \mathrm{~K}$. Figure 5 presents that at $\mathrm{CO}_{2} / \mathrm{CH}_{4}$ ration of 1 , higher fed $\mathrm{O}_{2}$ leads to lower carbon formation because more $\mathrm{O}_{2}$ introduced to the process can react more with carbon and forms $\mathrm{CO}$ and $\mathrm{CO}_{2}$. Supplying $\mathrm{O}_{2}$ where $\mathrm{O}_{2} / \mathrm{CH}_{4}$ ratio is higher than 0.15 , it causes no carbon formation in the process. Comparing with Fig. 4, it can be implied that carbon formation can be limited at lower $\mathrm{O}_{2}$ supply if the process is operated at higher temperature. At $\mathrm{O}_{2} / \mathrm{CH}_{4}$ ration of 0.2 and reaction temperature of $1050 \mathrm{~K}$, carbon formation cannot be investigated at $\mathrm{CO}_{2} / \mathrm{CH}_{4}$ ratio higher than 0.8 .

Effect of fed $\mathbf{C O}_{2}$ : The effect of $\mathrm{CO}_{2}$ fed in to the process is investigated here. As shown in Fig. 1, at $1050 \mathrm{~K}$, the $\mathrm{CH}_{4}$ conversion is $95 \%$ and Syngas concentration nearly reaches the maximum.

From Fig. $5, \mathrm{H}_{2} / \mathrm{CO}$ ratio is also about 1 at this reaction temperature. Thus, the reaction temperature is fixed at $1050 \mathrm{~K}$, while $\mathrm{CO}_{2}$ supplied to the system is varied to study its effect on gas production. The other reactants, e.g., $\mathrm{CH}_{4}$ and $\mathrm{O}_{2}$ are also fixed at $\mathrm{CH}_{4}: \mathrm{O}_{2}$ of 1.0:0.2. Moreover, at $1050 \mathrm{~K}$, solid carbon may not be observed. Even though the solid carbon is formed, its concentration is very low. Therefore, the equilibrium calculation omits to consider solid carbon.

Figure 7 exhibits the change of the mole fraction of some important products when $\mathrm{CO}_{2} / \mathrm{CH}_{4}$ ratio changes. The mole fraction of $\mathrm{H}_{2}$ increases from 0.45-0.516 when $\mathrm{CO}_{2} / \mathrm{CH}_{4}$ increases from 0 to 0.45 . Adding more $\mathrm{CO}_{2}$ into the process, it causes dropping $\mathrm{H}_{2}$ concentration. The similar behavior as $\mathrm{H}_{2}$ is observed from the change of $\mathrm{CO}$. The mole fraction of $\mathrm{CO}$ increases with increasing $\mathrm{CO}_{2}$ fed to the process. However, as seen from Fig. 7, CO starts to decrease when $\mathrm{CO}_{2} / \mathrm{CH}_{4}$ is equal to 1.0. From the above discussion, it can be implied that feeding more $\mathrm{CO}_{2}$ into the reactor, it may not provide good result. Excess $\mathrm{CO}_{2}$ cannot be converted and it leads to increase of $\mathrm{CO}_{2}$ in the product as exhibited in Fig. 7. The $\mathrm{H}_{2} \mathrm{O}$ content increases with increasing $\mathrm{CO}_{2} / \mathrm{CH}_{4}$. That is the effect of reverse water gas shift reaction. Figure 8 presents the change of mole of syngas in the product compared with the change of $\mathrm{CO}_{2} / \mathrm{CH}_{4}$ ratio. The concentration of syngas sharply increases when $\mathrm{CO}_{2} / \mathrm{CH}_{4}$ ratio increases. Nevertheless, the increase of syngas is hardly observed after $\mathrm{CO}_{2} / \mathrm{CH}_{4}$ ratio is higher than 1 . Finally, it can be concluded that at the reaction temperature of $1050 \mathrm{~K}$, the optimum $\mathrm{CO}_{2} / \mathrm{CH}_{4}$ ratio range based on syngas yield is $0.85-1.0$ and $\mathrm{CH}_{4}$ conversion in this range of $\mathrm{CO}_{2} / \mathrm{CH}_{4}$ ratio is 95.3-96.5\%. 


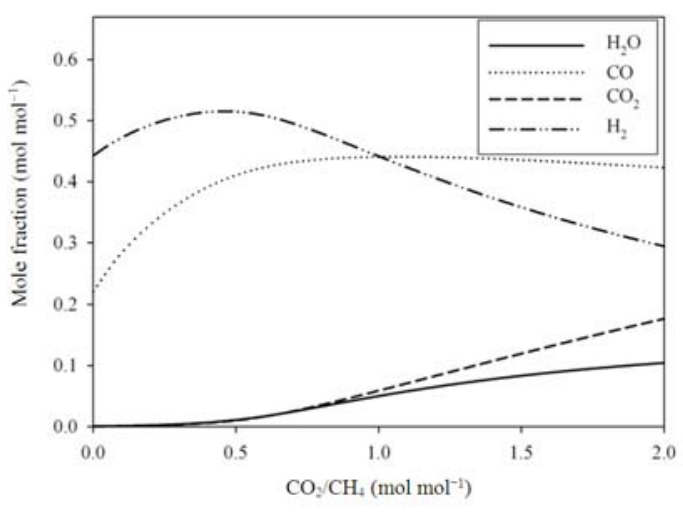

Fig. 7: Effect of $\mathrm{CO}_{2} / \mathrm{CH}_{4}$ ratio on gas compositions

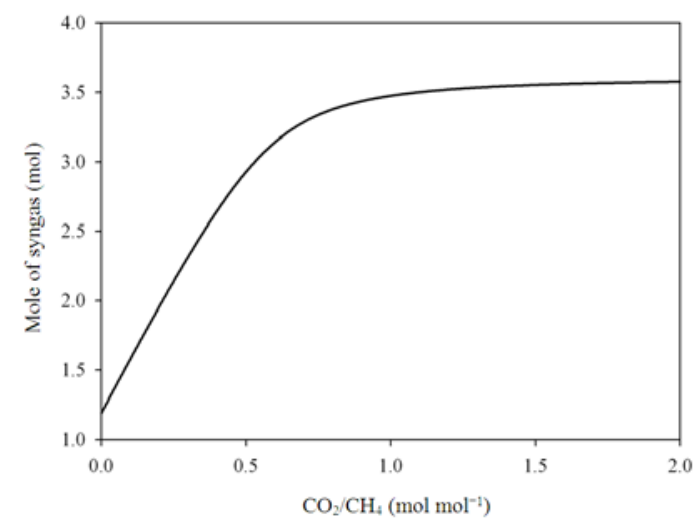

Fig. 8: Effect of $\mathrm{CO}_{2} / \mathrm{CH}_{4}$ ratio on syngas production

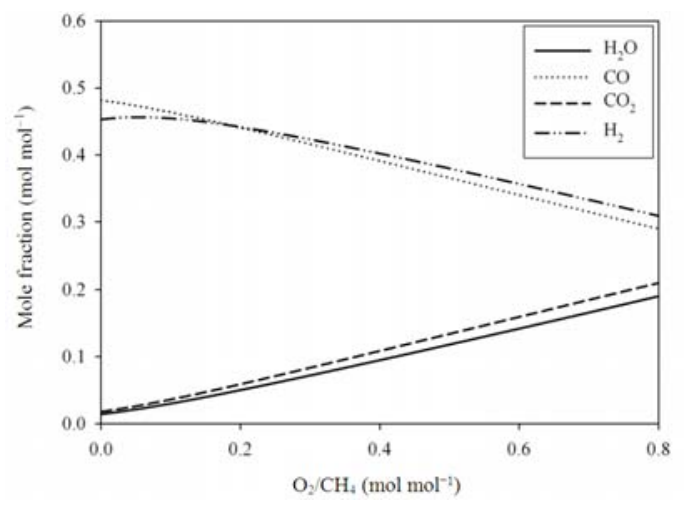

Fig. 9: Effect of $\mathrm{O}_{2} / \mathrm{CH}_{4}$ ratio on gas compositions

Effect of fed $\mathrm{O}_{2}$ : To study the effect of added $\mathrm{O}_{2}$ on the production of combined partial oxidation and $\mathrm{CO}_{2}$ reforming, the ratio of $\mathrm{CO}_{2} / \mathrm{CH}_{4}$ is fixed at 1 and the reaction temperature is also maintained at $1050 \mathrm{~K}$, while the ratio of $\mathrm{O}_{2} / \mathrm{CH}_{4}$ is varied from 0 to 0.8 . The results of equilibrium calculation are shows in Fig. 9 and 10. Figure 9 presents the mole fraction of $\mathrm{H}_{2} \mathrm{O}, \mathrm{H}_{2}$, $\mathrm{CO}$ and $\mathrm{CO}_{2}$. For $\mathrm{CO}$, when more $\mathrm{O}_{2}$ is added into the

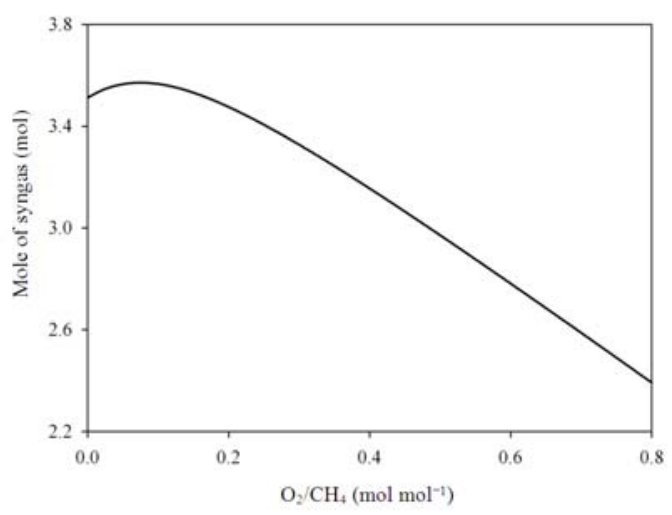

Fig. 10: Effect of $\mathrm{O}_{2} / \mathrm{CH}_{4}$ ratio on syngas production

process, its concentration starts to drop. However, $\mathrm{CO}_{2}$ concentration is observed that it increases when fed $\mathrm{O}_{2}$ increases. For the changes of $\mathrm{CO}$ and $\mathrm{CO}_{2}$ concentration, they can be explained that, more $\mathrm{O}_{2}$ added into the reactor causes $\mathrm{CH}_{4}$ conversion to $\mathrm{CO}_{2}$ and $\mathrm{H}_{2} \mathrm{O}$, that is reaction (1). Moreover, it is also due to $\mathrm{CO}$ and $\mathrm{H}_{2}$ oxidation with $\mathrm{O}_{2}$ formed $\mathrm{CO}_{2}$ and $\mathrm{H}_{2} \mathrm{O}$, respectively (Amin and Yaw, 2007). onsequently, $\mathrm{H}_{2}$ and $\mathrm{CO}$ contents reduce because they are converted to be $\mathrm{H}_{2} \mathrm{O}$ and $\mathrm{CO}_{2}$, respectively. This explanation is confirmed by increasing $\mathrm{H}_{2} \mathrm{O}$ and $\mathrm{CO}_{2}$ illustrated in Fig. 9. As seen from Fig. 10, the mole of syngas starts to reduce when $\mathrm{O}_{2} / \mathrm{CH}_{4}$ ratio is about 0.1. If the maximum syngas yield is considered, the optimum $\mathrm{O}_{2} / \mathrm{CH}_{4}$ ratio should be 0.1 . However, the $\mathrm{CH}_{4}$ conversion matching with $\mathrm{O}_{2} / \mathrm{CH}_{4}$ ratio of 0.1 is about 94\% and $97 \%$ of $\mathrm{CH}_{4}$ conversion can be achieved at $\mathrm{O}_{2} / \mathrm{CH}_{4}$ ratio of 0.2 . Therefore, the optimum rage of $\mathrm{O}_{2} / \mathrm{CH}_{4}$ ratio is $0.1-0.2$.

\section{CONCLUSION}

The thermodynamic equilibrium method was used to study combined partial oxidation and $\mathrm{CO}_{2}$ reforming process. Methane was employed as feedstock. The first part of this study was done based on $\mathrm{CH}_{4}: \mathrm{CO}_{2}: \mathrm{O} 2$ feed ratio of 1.0:1.0:0.2. The results showed that higher reaction temperature caused higher $\mathrm{CH}_{4}$ and $\mathrm{CO}_{2}$ conversions. $\mathrm{CO}$ and $\mathrm{H}_{2}$ production increased with increasing temperature. $\mathrm{H}_{2} / \mathrm{CO}$ ratio was about 1 when the reaction temperature was higher than $1000 \mathrm{~K}$. For syngas, it sharply increased at low temperature and slightly changed after $1000 \mathrm{~K}$. Solid carbon formation could not be observed after $1025 \mathrm{~K}$. The next study was carried out to investigate solid carbon formation due to the variation of $\mathrm{O}_{2} / \mathrm{CH}_{4}$ and $\mathrm{CO}_{2} / \mathrm{CH}_{4}$ rations at $1050 \mathrm{~K}$. It was found that solid carbon formation could be eliminated by increasing $\mathrm{O}_{2} / \mathrm{CH}_{4}$ and $\mathrm{CO}_{2} / \mathrm{CH}_{4}$ rations. The effect of fed $\mathrm{CO}_{2}$ and $\mathrm{O}_{2}$ on syngas production was 
observed at $1050 \mathrm{~K}$. For $\mathrm{O}_{2} / \mathrm{CH}_{4}$ higher than 0.1 , increase of $\mathrm{O}_{2} / \mathrm{CH}_{4}$ ration led decreasing $\mathrm{H}_{2}$ and $\mathrm{CO}$ in product gas while increase of $\mathrm{CO}_{2} / \mathrm{CH}_{4}$ ration caused increasing $\mathrm{H}_{2}$ and $\mathrm{CO}$. However, when $\mathrm{CO}_{2} / \mathrm{CH}_{4}$ ration was higher than 0.85 , increasing $\mathrm{CO}_{2} / \mathrm{CH}_{4}$ showed insignificantly change of syngas concentration. Finally, the results from this study presented that, at the reaction temperature of $1050 \mathrm{~K}$, the optimum range of $\mathrm{CH}_{4}: \mathrm{CO}_{2}: \mathrm{O}_{2}$ for combined partial oxidation and $\mathrm{CO}_{2}$ reforming process was $1: 0.85-1.0: 0.1-0.2$.

\section{REFERENCES}

Al-Mutairi, N. and P. Koushki, 2009. Potential contribution of traffic to air pollution in the state of Kuwait. Am. Environ. Sci., 5: 218-222. DOI: 10.3844/ajessp.2009.218.222

Amin, N.A.S. and TC. Yaw, 2007. Thermodynamic equilibrium analysis of combined carbon dioxide reforming with partial oxidation of methane to syngas. Int. J. Hydrogen Energy, 32: 1789-1798. DOI: 10.1016/J.IJHYDENE.2006.12.004

Bundela, P.S. and V. Chawla, 2010. Sustainable development through waste heat recovery. Am. J. Environ. Sci., 6: 83-89. DOI: 10.3844/ajessp.2010.83.89

Edwards, J.H., 1995. Potential sources of $\mathrm{CO}_{2}$ and the options for its large-scale utilisation now and in the future. Catalysis Today, 23: 59-66. DOI: 10.1016/0920-5861(94)00081-C

Froment, G.F., 2000. Production of synthesis gas by steam- and $\mathrm{CO}_{2}$-reforming of natural gas. J. Molecular Catalysis A., 163: 147-156. DOI: 10.1016/S1381-1169(00)00407-6

Haghighi, M., Z. Sun, J. Wu, J. Bromly and H.L. Wee et al., 2007. On the reaction mechanism of $\mathrm{CO}_{2}$ reforming of methane over a bed of coal char. Proc. Combustion Inst., 31: 1983-1990. DOI: 10.1016/J.PROCI.2006.07.029

Jarungthammachote, S. and A. Dutta, 2008. Equilibrium modeling of gasification: Gibbs free energy minimization approach and its application to spouted bed and spout-fluid bed gasifiers. Energy Conversion Manag., 49: 1345-1356. DOI: 10.1016/J.ENCONMAN.2008.01.006

Jarungthammachote, S., 2009. Thermodynamic analysis and exergy efficiency of methane authothermal reforming. J. Res. Eng. Technol., 6: 89-112.

Khademi, A., S. Babaei and A. Mataji, 2009. A study on potentiality of carbon storage and $\mathrm{CO}_{2}$ uptake in the biomass and soil of coppice stand. Am. J. Environ. Sci., 5: 346-351. DOI: 10.3844/ajessp.2009.346.351
Li, M.W., G.H. Xu, Y.L. Tian, L. Chen and H.F. Fu, 2004. Carbon dioxide reforming of methane using DC corona discharge plasma reaction. J. Physical Chem. A., 108: 1687-1693. DOI: 10.1021/jp037008q

McBride, B.J., S. Gordon and M.A. Reno, 1993. Coefficients for calculating thermodynamic and transport properties of individual species. NASA Technical Memorandum 4513, NASA. http://ntrs.nasa.gov/archive/nasa/casi.ntrs.nasa.gov/ 19940013151_1994013151.pdf

Nagaoka, K., K. Seshan, K. Aika and J.A. Lercher, 2001. Carbon deposition during carbon dioxide reforming of methane-comparison between $\mathrm{Pt} / \mathrm{Al}_{2} \mathrm{O}_{3}$ and $\mathrm{Pt} / \mathrm{ZrO}_{2}$. J. Catalysis, 197: 34-42. DOI: 10.1006/JCAT.2000.3062

Naito, S., H. Tanaka, S. Kado, T. Miyao and S. Naito et al., 2008. Promoting effect of Co addition on the catalytic partial oxidation of methane at short contact time over a $\mathrm{Rh} / \mathrm{MgO}$ catalyst. J. Catalysis, 259: 138-146. DOI: 10.1016/J.JCAT.2008.08.002

Puwanto, W.W. and Y. Muharam, 2006. Microreactor for the catalytic partial oxidation of methane. J. Natural Gas Chem., 15: 271-274. DOI: 10.1016/S1003-9953(07)60005-X

Shamsi, A. and C.D. Johnson, 2003. Effect of pressure on the carbon deposition route in $\mathrm{CO}_{2}$ reforming of ${ }^{13} \mathrm{CH}_{4}$. Catal Today, 84: 17-25. DOI: 10.1016/S0920-5861(03)00296-7

Tsang, S.C., J.B. Claridge and M.L.H. Green, 1995. Recent advances in the conversion of methane to synthesis gas. Catalysis Today, 23: 3-15. DOI: 10.1016/0920-5861(94)00080-L

Wang, W. and Y. Wang, 2008. Thermodynamic analysis of hydrogen production via partial oxidation of ethanol. Int. J. Hydrogen Energy, 33: 5035-5044.

DOI: 10.1016/J.IJHYDENE.2008.07.086

Wu, T., Q. Yan and H. Wan, 2005. Partial oxidation of methane to hydrogen and carbon monoxide over a $\mathrm{Ni} / \mathrm{TiO}_{2}$ catalyst. J. Molecular Catalysis A., 226: 41-48. DOI: 10.1016/J.MOLCATA.2004.09.016

Wurzel, T., S. Malcus and L. Mleczko, 2000. Reaction engineering investigations of $\mathrm{CO}_{2}$ reforming in a fluidized-bed reactor. Chem. Eng. Sci., 55: 3955-3966. DOI: 10.1016/S0009-2509(99)00444-3 